Abstracted/indexed in Academic Search Complete, Agroforestry Abstracts, Asia Journals Online, Bangladesh Journals Online, Biological Abstracts, BIOSIS Previews, CAB Abstracts, Current Abstracts, Directory of Open Access Journals, EMBASE/Excerpta Medica, Google Scholar, HINARI (WHO), International Pharmaceutical Abstracts, Open J-gate, Science Citation Index Expanded, SCOPUS and Social Sciences Citation Index

ISSN: $1991-0088$

\title{
Comparative study of antibacterial activity of wood-decay fungi and antibiotics
}

\section{A. F. Md. Hassan Iftekhar' ${ }^{1}$, Zubaida Khatoon Choudhry', Md. Ismail Khan' ${ }^{1}$ and Ahmed Abu Saleh²}

${ }^{1}$ Department of Pharmacology and Therapeutics, Dhaka Medical College, Dhaka 1000, Bangladesh; ${ }^{2}$ Department of Microbiology and Immunology, Bangabandhu Sheikh Mujib Medical University, Shahbag, Dhaka 1000, Bangladesh.

\begin{tabular}{|c|c|}
\hline \multicolumn{2}{|l|}{ Article Info } \\
\hline Received: & 13 June 2011 \\
\hline Accepted: & 22 June 2011 \\
\hline Available Online: & 30 June 2011 \\
\hline \multicolumn{2}{|c|}{ DOI: 10.3329/bjp.v6i1.7907 } \\
\hline \multicolumn{2}{|c|}{$\begin{array}{l}\text { Cite this article: } \\
\text { Iftekhar AFMH, Choudhry ZK, Kha } \\
\text { Khan MI, Saleh AA. Comparative } \\
\text { study of antibacterial activity of wood } \\
\text {-decay fungi and antibiotics. Bangla- } \\
\text { desh J Pharmacol. 2011; 6: 14-17. }\end{array}$} \\
\hline
\end{tabular}

\section{Abstract}

The antibacterial effects of three mushrooms extract Ganoderma lucidum, Auricularia auricula, Pleurotus florida were studied against Staphylococcus aureus and Escherichia coli. A. auricula showed significant antibacterial activity against $S$. aureus. P. florida showed some antibacterial activity while G. lucidum showed no antibacterial activity. None of the extracts showed any activity against E. coli.

\section{Introduction}

Whole world is frantically in search of new antibiotics because of an alarmingly increase in bacterial resistance to existing antibiotics due to their inappropriate and indiscriminate use. In search for new antibiotics, herbs and plants are being used.

Mushroom (wood-decay fungi) is considered to have antibacterial activity. Studies have been carried out using different mushroom extracts and different types of microorganisms (Fagade and Oyelda, 2009; Yoon et al., 1994; Quereshi et al., 2010; Gbolagade et al., 2007; Gezer et al., 2006; Sheena et al., 2003; Ishikawa and Kasuya, 2001). The response of microorganisms to mushroom extracts might vary depending upon the nature of environment in which it has been grown (Iwalokum et al., 2007). In this study, mushroom commonly grown in the natural environment of Bangladesh were taken to see their response to microorganisms. Two common microorganisms responsible for infection in everyday clinical practice, Staphylococcus aureus and Escherichia coli have been taken for the purpose. Most of the studies carried out, so far, showed inhibitory effect of mushroom on different microorganisms. In this study not only the inhibitory effect but also sensitivity pattern of mushroom extract on two microorganisms S. aureus and E. coli was studied and compared with commonly used antibiotics cloxacillin, cephradine, azithromycin and ciprofloxacin.

\section{Materials and Methods}

Two test organisms S. aureus (ATCC 22923) and E. coli (ATCC 25922) were collected from department of Microbiology and Immunology, Bangabandhu Sheikh Mujib Medical University. Ethanolic extracts of three wood decay fungi Ganoderma lucidum, Auricularia auricula, Pleurotus florida were prepared. Mushrooms were collected from National Mushroom Development and Extension Center, Savar, Dhaka, Bangladesh.

Preparation of wood decay extract: Mushrooms were cut, sun dried, grounded into powder and dissolved in 
absolute ethanol for 72 hours and stirred every 12 hours. It was then filtered through Whatman filter paper No. 1. The filtrate was concentrated at $40^{\circ} \mathrm{C}$ using a rotator evaporator (Fagade and Oyelade, 2009). The paste that was formed was freeze dried. Strict sterility was maintained through out the whole procedure. Six different concentration of each wood decay fungi were prepared by taking $75,125,250,500,750,1,000 \mathrm{mg}$ in 1 $\mathrm{mL}$ of sterile distilled water (for each concentration).

Determination of Minimum Inhibitory Concentration (MIC): Preserved microorganism S. aureus was subcultured in blood agar media and E. coli was subcultured in MacConcky's agar. Microorganisms were taken from both of these subcultures and inoculated in Muller Hinton agar plates. Different concentrations of wood decay fungi $75,125,250,500,750,1,000 \mathrm{mg} / \mathrm{mL}$ were taken and agar well diffusion method was applied (Aziz et al., 2007; Gazer et al., 2006; Gbolagade et al., 2007). The plates were left in the room temperature for 1 hour before incubation to allow effusion of the centre of the disc and average of the two reading was taken.

Interpretation of sensitivity: Zone of Inhibition produced by each antibacterial agents was considered into two categories namely sensitivity (S) and resistant (R) with the help of CLSI (NCCLS) 2010 and as per manufacturers (HIMEDIA).

\section{Results}

The zone of inhibition of $S$. aureus against azithromycin, cephradine, ciprofloxacin ranged from $24.0 \pm 3.1$ to $25.2 \pm 1.5 \mathrm{~mm}$ respectively and cloxacillin showed minimum zone of inhibition $10.8 \pm 0.8 \mathrm{~mm}$ (Table I).

In $1000 \mathrm{mg} / \mathrm{mL}$ concentration $A$. auricula showed significant zone of inhibition $14.2 \pm 1.7 \mathrm{~mm}$, where as $P$. florida exhibited zone of inhibition $12.7 \pm 3.3 \mathrm{~mm}$ and $\mathrm{G}$. lucidum $10.5 \pm 0.6 \mathrm{~mm}$ in same concentration. A. auricular's zone of inhibition was $>13 \mathrm{~mm}$ and $P$. florida

\begin{tabular}{|c|c|c|c|c|c|c|c|}
\hline \multicolumn{8}{|c|}{ Table I } \\
\hline \multicolumn{8}{|c|}{$\begin{array}{l}\text { Zone of inhibition of wood-decay fungi (mushroom) extracts and drugs discs against two bacteria Staphylo- } \\
\qquad \text { coccus aureus and Escherichia coli }\end{array}$} \\
\hline \multirow[t]{2}{*}{ Organisms } & \multirow{2}{*}{$\begin{array}{l}\text { Mushroom } \\
\text { extracts } \\
(\mathrm{mg} / \mathrm{mL})\end{array}$} & \multicolumn{3}{|c|}{ Zone of inhibition (mm) } & \multicolumn{2}{|c|}{$\begin{array}{l}\text { Drug's disc potency } \\
(\mu \mathrm{g} / \text { discs })\end{array}$} & \multirow{2}{*}{$\begin{array}{c}\text { Control } \\
\text { (Distilled } \\
\text { water } \\
60 \mu \mathrm{L} / \text { well) }\end{array}$} \\
\hline & & $\begin{array}{l}\text { Ganoderma } \\
\text { lucidum }\end{array}$ & $\begin{array}{l}\text { Auricularia } \\
\text { auricula }\end{array}$ & $\begin{array}{l}\text { Pleurotus } \\
\text { florida }\end{array}$ & Antibiotics & $\begin{array}{l}\text { Zone of } \\
\text { inhibition }\end{array}$ & \\
\hline \multirow{6}{*}{$\begin{array}{l}\text { Staphylococcus } \\
\text { aureus (ATCC } \\
\text { 22923) }\end{array}$} & 75 & 0 & 0 & 0 & Cloxacillin & $10.8 \pm 0.8$ & 0 \\
\hline & 125 & 0 & 0 & 0 & & & \\
\hline & 250 & 0 & 0 & 0 & Azithromycin & $24.0 \pm 3.1$ & \\
\hline & 500 & $7.7 \pm 1.9$ & $10.8 \pm 2.6$ & $8.8 \pm 3.5$ & & & \\
\hline & 750 & $9.7 \pm 1.4$ & $12.3 \pm 3.4$ & $10.5 \pm 3.5$ & Cephradine & $24.7 \pm 2.2$ & \\
\hline & 1000 & $10.5 \pm 0.6$ & $14.2 \pm 1.7$ & $12.7 \pm 3.3$ & Ciprofloxacin & $25.2 \pm 1.5$ & \\
\hline \multirow{6}{*}{$\begin{array}{l}\text { Escherichia coli } \\
\text { (ATCC 25922) }\end{array}$} & 75 & 0 & 0 & 0 & Cloxacillin & 0 & 0 \\
\hline & 125 & 0 & 0 & 0 & Azithromycin & $26.7 \pm 4.1$ & \\
\hline & 250 & 0 & 0 & 0 & & & \\
\hline & 500 & 0 & 0 & 0 & Cephradine & $17.0 \pm 2.8$ & \\
\hline & 750 & 0 & 0 & 0 & Ciprofloxacin & $40.8 \pm 4.1$ & \\
\hline & 1000 & 0 & 0 & 0 & & & \\
\hline
\end{tabular}

extracts into agar well. Test antibiotics in the strength of cloxacillin $1 \mu \mathrm{g} /$ disc, azithromycin $15 \mu \mathrm{g} /$ disc, cephradine $25 \mu \mathrm{g} /$ disc, ciprofloxacin $5 \mu \mathrm{g} /$ disc were placed on their particular mark point just before incubation. The discs were incubated at $37^{\circ} \mathrm{C}$ for 24 hours.

At the end of this period MIC was measured with the help of scale on the under surface petri dish without opening the lid. Zone of inhibition was measured in two directions at right angle to each other from the and G. lucidum's zone of inhibition was $<13 \mathrm{~mm}$ (p $<0.05)$ compared to cloxacillin, which exhibited minimum zone of inhibition on $S$. aureus and standard zone of inhibition was taken $>13 \mathrm{~mm}$. When sensitivity pattern of these extracts were compared with cloxacillin, azithromycin, cephradine and ciprofloxacin, $A$. auricula was significantly sensitive to $S$. aureus and $P$. florida and G. lucidum were not sensitive. None of the three extracts showed any inhibition and sensitivity to E. coli in highest concentration (Table II). 


\section{Table II}

\begin{tabular}{|c|c|c|c|c|c|c|c|}
\hline \multirow[t]{2}{*}{ Organisms } & \multirow{2}{*}{$\begin{array}{l}\text { Mushroom } \\
\text { extracts } \\
(\mathrm{mg} / \mathrm{mL})\end{array}$} & \multicolumn{3}{|c|}{ Mushroom's sensitivity and resistance pattern } & \multicolumn{3}{|c|}{ Antibiotics sensitivity and resistance pattern } \\
\hline & & $\begin{array}{l}\text { Ganoderma } \\
\text { lucidum }\end{array}$ & $\begin{array}{c}\text { Auricularia } \\
\text { auricula }\end{array}$ & Pleurotus florida & $\begin{array}{l}\text { Antibiotics } \\
\text { used }\end{array}$ & Sensitivity & Resistance \\
\hline \multirow{6}{*}{$\begin{array}{l}\text { Staphylococcus } \\
\text { aureus } \\
\text { (ATCC 22923) }\end{array}$} & 75 & $(\mathrm{R})$ & $(\mathrm{R})$ & (R) & Cloxacillin & & (R) \\
\hline & 125 & $(\mathrm{R})$ & $(\mathrm{R})$ & (R) & & & \\
\hline & 250 & $(\mathrm{R})$ & (R) & $(\mathrm{R})$ & Azithromycin & $S(++)$ & \\
\hline & 500 & (R) & (R) & $(\mathrm{R})$ & & & \\
\hline & 750 & $(\mathrm{R})$ & (R) & $(\mathrm{R})$ & Cephradine & $S(++)$ & \\
\hline & 1000 & $(\mathrm{R})$ & $\mathrm{S}(+)$ & (R) & Ciprofloxacin & $\mathrm{S}(+++)$ & \\
\hline \multirow{6}{*}{$\begin{array}{l}\text { Escherichia coli } \\
\text { (ATCC 25922) }\end{array}$} & 75 & (R) & $(\mathrm{R})$ & (R) & Cloxacillin & & $(\mathrm{R})$ \\
\hline & 125 & (R) & (R) & (R) & Azithromycin & $S(+++)$ & \\
\hline & 250 & (R) & (R) & (R) & & & \\
\hline & 500 & (R) & (R) & (R) & Cephradine & $S(+)$ & \\
\hline & 750 & (R) & (R) & (R) & Ciprofloxacin & $S(++++)$ & \\
\hline & 1000 & (R) & (R) & (R) & & & \\
\hline
\end{tabular}

\section{Discussion}

Of the three wood-decay fungi G. lucidum showed zone of inhibition similar to that of Cloxacillin, where as $A$. auricula and $P$. florida showed higher zone of inhibition. Significant zone of inhibition was exhibited only by $A$. auricula.

When sensitivity pattern of different wood-decay fungi extracts was compared only $A$. auricula showed significant sensitivity to $S$. aureus $(>13 \mathrm{~mm})$. The zone of inhibition and sensitivity of $P$. florida was very near to the standard taken, which is suggestive that higher dose of P. florida might show sensitivity to S. aureus. G. lucidum showed resistance. None of the extracts showed inhibition and sensitivity to test organism E. coli.

In a more or less similar study (Fagade and Oyelade, 2009) inhibitory effect of G. lucidum, A. auricula and $P$. florida was observed against $S$. aureus and E. coli, where A. auricula and $P$. florida showed antibacterial activity against both the organisms. In this study only $A$. auricula showed significant and $P$. florida showed moderate inhibitory effect and sensitivity to $S$. aureus. None of the three extracts exhibited any inhibitory or sensitivity to E. coli.

This difference in response of mushroom extracts to test organisms might be due to a number of factors, as studies suggest that the antimicrobial activities of all mushroom extracts are changeable (Iwalokun et al., 2007), depending upon the nature of environment and media in which it is grown. It also depends upon the genetic structure of mushroom species, physical and biochemical constituent's differences of mushroom extracts solvents and test organisms. The sensitivity pattern of microorganisms also changes to chemotherapeutic agents depending on their strains, and susceptibility or resistance to antibiotic (Gao et al., 2005).

Studies using different test organisms and different mushroom extracts also showed that mushroom posses antibacterial activity to varying degrees (Gazer et al., 2006; Upadhyay et al., 2010; Kim et al., 2001). Antibacterial activity of mushroom extracts have been attributed to presence of biologically active compounds. Studies suggest that these biologically active compounds enhance immunity (Ramesh and Pattar, 2010) and they also posses antitumor properties. The antibacterial and antitumor properties of mushroom have been attributed to presence of polysaccharides, terpens and lectins. Studies suggested that polysaccharides from mushrooms do not act directly but modify the different immune responses in the host mainly by increasing macrophage activity that destroy pathogens such as bacteria, virus etc (Wasser and Weis, 1999). In addition to their immunomodulating effect they have significant cardioprotective, antiparasitic, hepatoprotective and antidiabetic effect (Wasser and Weis, 1999).

Mushroom taken as food has the advantage of being devoid of dose related adverse effect seen with antibiotics. Resistance to antibiotics due to its frequent and inappropriate use pose a threat to treatment of bacterial infections mostly in under developed countries and in many developed countries of the 
world as well. Therefore mushroom with antibacterial properties have received considerable attention in recent years. Search for new antimicrobial agents has gained considerable importance, and mushrooms for their antibacterial activity may be considered for their easy availability and cheapness. Some times antibiotic combinations are being used to overcome the problems of drug resistance (Lewin et al., 1991; Kim et al., 2001), but use of two or more antibiotics carries more chance of antibiotics related adverse effect and use of mushroom along with antibiotics might help lessen the adverse effects (Kim et al., 2001).

\section{Conclusion}

Mushroom extracts can be used to combat pathogenic microorganisms along with available antibiotics.

\section{Acknowledgements}

The authors are grateful to Prof. Mir Misbahuddin and Dr. Abu Naser Ibne Sattar of Bangabandhu Sheikh Mujib Medical University and Dr. Badar Uddin Omar of Dhaka Medical College for their support and technical help.

\section{References}

Ananthanarayan R, Jayaram PCK. Textbook of microbiology. $5^{\text {th }}$ ed. Chennai, India, Orient Longman Ltd, 1997, pp 53-55.

Aziz T, Mehmet ED, Nazime M. Anti-oxidant and antimicrobial activity of Russula delica Fr: An edible wild mushroom. Eurasian J Analy Chem. 2007; 2: 54-67.

Choudhury MR. Modern medical microbiology. $5^{\text {th }}$ ed. Bishwa Parichaya, 1999, pp 8-17.

Clark AM, Ei-Feraly FS, Li WS. Antimicrobial activity of phenolic constituents of Magnolia grandiflora L. J Pharm Sci. 1981; 70: 951-52.

Fagade OE, Oyelade AA. A Comparative study of the antibacterial activities of some wood-decay fungi to synthetic antibiotic discs. EJEAF Che. 2009; 8: 184-88.

Gani A. Medicinal plants of Bangladesh with chemical constituents \& use. 2nd ed. Dhaka, Bangladesh, Asiatic Society of Bangladesh, 2003, pp 33-45.

Gao Y, Tang W, Gao H, Chan E, Lan J, Li X, Zhou S. Antibacterial activity of medicinal mushroom Ganoderma. Food Rev Int. 2005; 21: 211-29.
Gbolagade J, Kigigha L, Ohimain E. Antagonist effect of extracts of some Nigirian higher fungi against selected pathogenic micro-organisms. American-Eurasian J Agri Environ Sci. 2007; 2: 364-68.

Gezer K, Duru ME, Kivrak I, Turkoglu A, Mercan N, Turkoglu $\mathrm{H}$, Gulcan S. Free-radical scavenging capacity and antimicrobial activity of wild edible mushroom from Turkey. African J Biotech. 2006; 5: 1924-28.

Ishikawa NK, Kasuya MCM. Antibacterial activity of Lentinula edodes grown in liquid medium. Braz J Microbiol. 2001; 32: 19.

Iwalokun BA, Usen UA, Otunba AA, Olukoya DK. Comparative phytochemical evaluation, antimicrobial and antioxidant properties of Pleurotus ostreatus. African J Biotech. 2007; 6: 1732-39.

Kim YS, Eo SK, Oh KW, Lee CK, Lee YN, Han SS. Antibacterial activity of water soluble components of Elfoingia applanata alone and in combination with quinolones. Korean Soc Myco Biol. 2001; 29: 11-14.

Laurance DR, Bennett PN, Brown MJ. Clinical pharmacology. $8^{\text {th }}$ ed. Singapore, Longman, 2000, p 187, 192.

Lewin CS, Morrissey I, Smith JT. The mode of action of quinolones: The paradox in activity of low and high concentrations and activity in the anaerobic environment. Eur J Clin Microbiol Infect Dis. 1991; 10: 240-48.

Park K. Park's Textbook of preventive social medicine. $14^{\text {th }}$ ed. Jabalpur, India, Banarsidas Bhont Publishers, 1994, p 522.

Quereshi S, Pandey AK, Sandhu SS, Evaluation of antibacterial activity of different Ganoderma lucidum extracts. Peoples J Sci Res. 2010; 3: 9-13.

Ramesh CH, Pattar MG. Antimicrobial properties, antioxidant activity and bioactive compounds from six wild edible mushrooms of Western ghat of Karnataka, India. Pharmacog Res J. 2010; 2: 107-12.

Sheena N, Azith TA, Thomas A, Mathew, Jonardhan KK. Antibacterial activity of three macro fungi Ganoderma Lucidum, Navesporus floccose and Phellium rimosus occuring in south India. J Pharmaceutical Biol. 2003; 41: 564-67.

Upadhyay RK, Ahmad S, tripathi R, Rohtagi L, Jain SC. Screening of antimicrobial potential of extracts and pure compounds isolated from Capparis deciduas. J Med Plants Res. 2010; 4: 439-45.

Wasser SP, Weis AL. Medicinal properties of substances occurring in higher Basidiomycetes mushrooms: Current Prespectives. Int J Med Mushrooms. 1999; 1: 47-50.

Yoon SY, Eo SK, Kim YS, Lee CK, Han SS. Antibacterial activity of Ganoderma lucidum extract alone and in combination with some antibiotics. Arch Pharm Res. 1994; 17: 438-42. 